\title{
PENGARUH SISTEM BAGI HASIL DEPOSITO TERHADAP PERSEPSI NASABAH
}

\author{
Devi Wahyu Arianti, Khodijah Ishak \\ Sekolah Tinggi Ilmu Ekonomi Syariah Bengkalis \\ deviwa01@gmail.com,khodijahishak2@gmail.com \\ https://doi.org/10.46367/jps.v1i2.237
}

Received: Sep 01, 2020 Revised: Sep 30, 2020 Accepted: Oct 02, 2020 Published: Oct 12, 2020

\begin{abstract}
Banking is a financial institution that provides services and facilities to its customers who wish to conduct financial transactions. Bank Syariah Mandiri is a sharia financial institution that offers mudharabah time deposits with a profitsharing agreement. This study aims to determine the effect of the deposit sharing system on customer perceptions at Bank Syariah Mandiri Bengkalis Sub-Branch Office. This research uses quantitative methods with the number of respondents as many as 110 customers. Based on the results of the calculation of the correlation between profit-sharing with customer perceptions has a positive relationship. Then there is a significant influence between profit-sharing on customer perceptions at Bank Syariah Mandiri Bengkalis Sub Branch Office.
\end{abstract}

Keywords: Profit Sharing, Customer Perception, Time Deposit, Bank Syariah Mandiri.

\begin{abstract}
ABSTRAK
Perbankan merupakan lembaga keuangan yang menyediakan layanan dan kemudahan kepada nasabahnya yang ingin melakukan transaksi keuangan. Bank Syariah Mandiri merupakan salah satu lembaga keuangan syariah yang menawarkan simpanan mudharabah berjangka (deposito) dengan akad bagi hasil. Penelitian ini bertujuan untuk mengetahui pengaruh sistem bagi hasil deposito terhadap presepsi nasabah pada Bank Syariah Mandiri Kantor Cabang Pembantu Bengkalis. Penelitian ini menggunakan metode kuantitatif dengan jumlah responden sebanyak 110 orang nasabah. Berdasarkan hasil perhitungan korelasi antara bagi hasil dengan persepsi nasabah memiliki hubungan positif. Kemudian terdapat pengaruh yang signifikan antara bagi hasil terhadap persepsi nasabah pada Bank Syariah Mandiri Kantor Cabang Pembantu Bengkalis.
\end{abstract}

Kata Kunci: Bagi Hasil, Persepsi Nasabah, Deposito, Bank Syariah Mandiri.

\section{PENDAHULUAN}

Bank syariah merupakan bank yang secara operasional berbeda dengan bank konvensional. Salah satu ciri khas bank syariah yaitu tidak menerima atau membebani bunga kepada nasabah, akan tetapi menerima atau membebankan bagi 
hasil serta imbalan lain sesuai dengan akad-akad yang diperjanjikan. Indonesia merupakan salah satu negara yang menerapkan Inflation Targeting Framework (ITF) dengan asumsi inflasi year on year terakhir yang ditetapkan oleh pemerintah di dalam PBN-P 2015 sebesar 5\% sedangkan perkiraan realisasi sebesar 4\%. Sementara itu, Badan Pusat Statistik (BPS) mencatat inflasi dari januari 2015 sampai dengan juli 2015 sebesar 3,35\% dan inflasi year on year periode juli (2014-2015) sebesar 8,36\%. Hal ini menunjukkan bahwa realisasi sampai dengan bulan juli 2015 telah melebihi target yang diterapkan pemerintah.

Menurut Harahap $(2004,95)$ cara operasi bank syariah hakikatnya sama saja dengan bank konvensional, yang berbeda hanya dalam masalah bunga dan praktik lainnya yang menurut syariat islam tidak dibenarkan. Menurut para fuqaha, mudharabah adalah aqad antara dua pihak saling menanggung, salah satu pihak menyerahkan hartanya kepada pihak lain untuk diperdagangkan dengan bagian yang telah ditentukan dari keuntungan, seperti setengah atau sepertiga dengan syarat-syarat yang telah ditentukan.

Bagi untung (Profit Sharing) adalah bagi hasil yang dihitung dari pendapatan setelah dikurangi biaya biaya pengelolaan dana. Dalam sistem syariah pola ini dapat digunakan untuk keperluan distribusi hasil usaha lembaga keuangan syariah. Bagi hasil (Revenue Sharing) adalah bagi hasil yang dihitung dari total pendapatan pengelolaan dana. Dalam sistem syariah pola ini dapat digunakan untuk keperluan distribusi hasil usaha lembaga keuangan syariah.

Untuk menghindarkan masyarakat Islam terlibat amalan riba Bank Syariah Mandiri KCP Bengkalis pada tahun 2010 telah membuka produk-produk tabungan Bank dengan akad mudharabah diantaranya, Tabungan BSM Investa Cendekia, Tabungan Berencana BSM, Deposito BSM, Tabungan BSM dan lain sebagainya. Sedangkan produk tabungan Bank dengan akad wadi'ah yaitu, Tabungan Simpatik, Tabungan Giro BSM, dan Tabungan Ku.

Bank Syari'ah Mandiri (BSM) KCP Bengkalis merupakan salah satu lembaga keuangan syariah yang menawarkan simpanan mudharabah berjangka (deposito).yang penarikannya hanya dapat dilakukan pada waktu tertentu berdasarkan perjanjian yang telah ditentukan antara nasabah dengan pihak bank.Terkadang ada anggota bank syariah mandiri yang membutuhkan simpanan tersebut untuk kepentingan mendadak, akhirnya dengan terpaksa anggota menarik simpanan tersebut sebelum jatuh tempo. Karena anggota tersebut mengambil simpanannya sebelum jatuh tempo maka pihak bank akan memotong atau mengenakan penalti simpanan tersebut. Namun masih ada nasabah deposito yang tidak memehami konsep akad yang digunakan dalam investasi berjangka (deposito). Penghimpunan dana deposito hanya ditawarkan kepada sebagian kalangan masyarakat yang dianggap mampu / kelebihan dana. Pihak bank syariah jarang mempromosikan sistem bagi hasil kepada nasabah yang datang dalam pembukaan tabugan ataupun dalam penyimpanan dana yang dilakukan oleh pengusaha kecil menegah, sehingga Masih sempitnya pengetahuan masyarakat tentang strategi bagi hasil pada produk tabungan BSM. 


\section{TELAAH LITERATUR}

\section{Bagi Hasil}

Menurut Antonio (2001, 90), bagi hasil adalah suatu sistem pengolahan dana dalam perekonomian Islam yakni pembagian hasil usaha antara pemilik modal (shahibul maal) dan pengelola (mudharib).

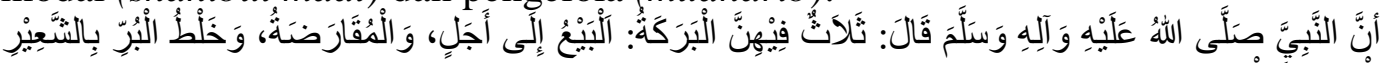

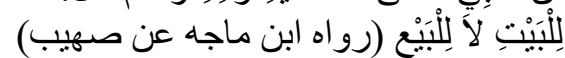

Artinya: "Nabi bersabda, ada tida hal yang mengandung berkah; jual beli tidak secara tunai, muqaradhah (mudharabah), dan mencampur gandum dengan jewawut untuk keperluan rumah tangga, bukan untuk dijual." (HR. Ibnu Majah dari Shuhaib) (Suhendi 2002, 139)

Bagi hasil (Basil) adalah sistem dalam pembagian pendapatan/hasil usaha yang dilakukan oleh pemilik modal (shahibul maal) dengan pengelola dana (mudharib) (Ridwansyah 2013, 33).

Pembiayaan dengan pola bagi hasil diterapkan untuk pembiayaan produktif dimana usaha yang dibiayai akan menghasilakan suatu keuntungan atau revenue. Bank diawal akad akan menghitung pendapatan yang diharapkan (expected return) bila bank memberikan pembiayaan kepada nasabah. Selanjutnya expected return tersebut akan disimulasikan dengan proyeksi revenue dari usaha yang dibiayai akan dihasilakan suatu angka proporsi bagi hasil antara bank dan nasabah yang disebut dengan nisbah. Nisbah inilah yang akan menjadi patokan bagi bank dan nasabah dalam berbagi hasil (Laksmana 2009, 77).

Didalam laporan keuangan bank Islam terdapat beberapa pos yang mempengaruhi unsur perhitungan bagi hasil, yaitu: (1) Pendapatan margin dan pendapatan bagi hasil, dihitung berdasarkan perolehan pendapatan pada bulan berjalan. (2) Saldo dana pihak ketiga, yang dihitung dengan menggunakan saldo rata-rata harian bulan bersangkutan. (3) Pembiayaan, yang dihitung berdasarkan saldo rata-rata harian bulan bersangkutan. Ada pula pendapatan bahwa yang di ambil adalah saldo rata-rata harian bulan sebelumnya, dengan alasan karena yang memengaruhi pendapatan bulan berjalan adalah pembiayaan bulan sebelumnya, sedangkan pembiayaan bulan berjalan baru akan memperoleh pendapatan pada bulan berikutnya. (4) Investasi pada surat berharga/penempatan pada bank islam lain. (5) Penentuan kapan bagi hasil efektif dibagikan kepada para pemilik dana, apakah mingguan, pada bulan akhir, pada tanggal valuta, pada tanggal jatuh tempo, pada akhir tahun dan lain. (6) Penggunaan bobot dalam menghitung besarnya dana pihak ketiga.

\section{Deposito}

Deposito adalah simpanannya yang penarikannya hanya dapat dilakukan pada waktu tertentu berdasarkan perjanjian antara nasabah dengan bank. Transaksi penanaman dana dari pemilik dana (shahibul maal) kepada pengelola dana (mudharib) untuk melakukan kegiatan usaha tertentu sesuai syariah, dengan pembagian hasil usaha antara kedua belah pihak berdasarkan nisbah yang telah disepakati sebelumnya (Muhamad 2014, 38).

Deposito merupakan dana nasabah yang ada pada bank yangpenarikannya dapat dilakukan pada saat jatuh tempo atau jangka waktu yangditentukan. 
Misalnya 3 bulan, 6 bulan, dan seterusnya. Pada produk deposito ini bank menggunakan prinsip bagi hasil (Anshari 2007, 94).

Sumber dana dari masyarakat luas yang ketiga adalah simpanan deposito dan pemilik deposito disebut deposan. Berbeda dengan dua jenis simpanan sebelumnya, di mana simpanan deposito mengandung unsur jangka waktu (jatuh tempo) lebih panjang dan dapat ditarik atau dicairkan setelah jatuh tempo. Begitu juga dengan suku bunga yang relatif tinggi dari kedua jenis simpanan sebelumnya (Kasmir 2006, 62).

\section{Persepsi Nasabah}

Persepsi merupakan proses individu (konsumen) memilih, mengorganisasi, menginterpretasi (memaknai) masukan-masukan informasi yang dapat menciptakan gambaran objek yang memiliki kebenaran subjektif (bersifat personal), memiliki arti tertentu, dapat dirasakan melalui perhatian, baik secara selektif,distrorsi maupun retensi.

Persepsi nilai tergantung pada cara pelanggan menghubungkan baerbagai atribut produk yang relavan dengan dirinya sendiri. Konsekuensi-konsekuensi yang relavan dengan dirinya sendiri dapat berbeda-beda pada bebagai tingkatan yang lebih abstraks. Kuat tidaknya persepsi pada konsumen sangat tergantung pada berbagai daya tarik dan kesesuaian objek dengan individu yang bersangkutan. Persepsi dapat digunakan sebagai model riset persepsi nilai dan dapat juga sebagai teori persepsi nilai dan keputusan pembelian (Hasan 2010, 67).

Berdasarkan Undang-Undang Republik Indonesia nomor 21 tahun 2008 tentang perbankan syariah, nasabah adalah pihak yang menggunakan jasa bank syariah dan atau Unit Usaha Syariah. Nasabah penyimpan adalah nasabah yang menempatkan dananya di bank syariah dan atau unit usaha syariah dalam bentuk simpanan berdasarkan akad antara bank syariah atau unit usaha syariah dan nasabah yang bersangkutan (Syamsurizal 2012).

Dari penjelasan teori diatas maka dapat dibuat hipotesis yaitu bagi hasil memiliki hubungan positif dengan persepsi nasabah. Kemudian adanya pengaruh yang signifikan antara bagi hasil terhadap persepsi nasabah pada Bank Syariah Mandiri Kantor Cabang Pembantu Bengkalis.

\section{METODE PENELITIAN}

Penelitian ini dilaksanakan di PT. Bank Syariah Mandiri Kantor Cabang Pembantu Bengkalis. Teknik pengumpulan data yang digunakan adalah wawancara, kuesioner/angket, observasi dan dokumentasi. Sedangkan metode yang digunakan adalah kuantitatif. Sedangkan jumlah data persepsi nasabah dengan responden 110 orang. Teknik analisis data yang digunakan adalah regresi linear sederhana. 


\section{HASIL DAN PEMBAHASAN PENELITIAN}

Uji Validitas

Tabel 1 Uji Validitas Data Kuesioner Responden

\begin{tabular}{cccc}
\hline Item & $\mathbf{r}_{\text {hitung }}$ & $\mathbf{r}_{\text {tabel }}$ & Keterangan \\
\hline Pertanyaan 1 & 0,275 & 0,1857 & Valid \\
Pertanyaan 2 & 0,475 & 0,1857 & Valid \\
Pertanyaan 3 & 0,422 & 0,1857 & Valid \\
Pertanyaan 4 & 0,591 & 0,1857 & Valid \\
Pertanyaan 5 & 0,481 & 0,1857 & Valid \\
Pertanyaan 6 & 0,485 & 0,1857 & Valid \\
Pertanyaan 7 & 0,554 & 0,1857 & Valid \\
Pertanyaan 8 & 0,636 & 0,1857 & Valid \\
Pertanyaan 9 & 0,590 & 0,1857 & Valid \\
Pertanyaan 10 & 0,412 & 0,1857 & Valid \\
Pertanyaan 11 & 0,290 & 0,1857 & Valid \\
Pertanyaan 12 & 0,554 & 0,1857 & Valid \\
Pertanyaan 13 & 0,588 & 0,1857 & Valid \\
Pertanyaan 14 & 0,426 & 0,1857 & Valid \\
Pertanyaan 15 & 0,367 & 0,1857 & Valid \\
Pertanyaan 17 & 0,491 & 0,1857 & Valid \\
Pertanyaan 18 & 0,498 & 0,1857 & Valid \\
\hline Sumber: data olahan & & &
\end{tabular}

Berdasarkan Tabel 1 yang dilakukan peneliti dapat dikatakan bahwa semua item pernyataan variabel bagi hasil terhadap persepsi nasabah mempunyai nilai korelasi (r) yang lebih besar dari $r_{\text {tabel }}$ yaitu 0,1857 yang dimaksud semua pernyataan dapat dikatakan valid dan dapat digunakan untuk instrumen penelitian.

\section{Uji Reliabilitas}

Tabel 2 Uji Reabilitas Data

\begin{tabular}{ccc}
\hline $\begin{array}{c}\text { Cronbach's } \\
\text { Alpha }\end{array}$ & $\begin{array}{c}\text { Cronbach's Alpha } \\
\text { Based on Standardized } \\
\text { Items }\end{array}$ & N of Item \\
\hline, 865 &, 864 & 18 \\
\hline Sumber: output SPSS & &
\end{tabular}

Tabel 2 menunjukkan hasil pengujian reabilitas dilihat dari cronbach's alpha 0,865>0,60. Sehingga dapat dikatakan bahwa seluruh variabel yang digunakan tersebut reliabel digunakan untuk penelitian. 


\section{Uji Normalitas}

Tabel 3 One-Sample Kolmogorov-Smirnov Test

\begin{tabular}{llc}
\hline & & $\begin{array}{c}\text { Unstandardized } \\
\text { Residual }\end{array}$ \\
\hline$N$ & 110 \\
Normal Parameters $^{a}$ & Mean &, 0000000 \\
& Std. Deviation & 3,94289495 \\
Most Extreme & Absolute &, 079 \\
Differences & Positive &, 079 \\
& Negative &,- 072 \\
Kolmogorov-Smirnov Z &, 825 \\
Asymp. Sig. (2-tailed) &, 503 \\
\hline a. Test distribution is Normal. & \\
Sumber: output SPSS &
\end{tabular}

Hasil uji normalitas pada Tabel 3 dapat dilihat nilai asymp.sig. sebesar 0,503>0,05. Dapat dikatakan bahwa model regresi memenuhi asumsi normalitas.

\section{Uji Regresi Linier Sederhana}

Tabel 4 Correlations

\begin{tabular}{llcc} 
& & Bagi Hasil & $\begin{array}{c}\text { Persepsi } \\
\text { Nasabah }\end{array}$ \\
$\begin{array}{l}\text { Pearson } \\
\text { Correlation }\end{array}$ & Bagi Hasil & 1.000 & .692 \\
\hline \multirow{2}{*}{ Sig. (1-tailed) } & Persepsi Nasabah &, 692 & 1.000 \\
\cline { 2 - 4 }$N$ & Persepsi Nasabah &, 000 &, 000 \\
\multirow{2}{*}{$N$} & Bagi Hasil & 110 &, \\
\hline Sumber: output SPSS & Persepsi Nasabah & 110 & 110 \\
\end{tabular}

Berdasarkan Tabel 4 di atas, dapat dilihat hasil perhitungan korelasi antara Bagi Hasil dan Persepsi Nasabah $=0,692$ dan nilai sig $(\mathrm{P}$ value $)=0,000$. Berdasarkan patokan nilai hubungan variabel menurut Sugiyono bahwa 0,692 besar $(0,692-1)$ dan searah karena nilainya positif. Angka probilitas dari hasil perhitungan $0,000 \leq 0,05$ maka hipotesis diterima. Artinya ada hubungan antara bagi hasil dengan persepsi nasabah.

Tabel 5 Paired Samples Correlations

\begin{tabular}{lccc}
\hline & $N$ & Correlation & Sig. \\
\hline Pair 1 Bagi Hasil \& Persepsi Nasabah & 110 &, 692 &, 000 \\
\hline Sumber: output SPSS & & &
\end{tabular}


Berdasarkan Tabel 5 hasil korelasi antara kedua variabel yang menghasilkan angka 0,692 dengan nilai probabilitas (sig) 0,000. Hal ini menyatakan bahwa korelasi antara bagi hasil dan persepsi nasabah berhubungan secara nyata. Karena nilai probabilitas $(0,000<0,05)$.

Tebel 6 Coefficients ${ }^{\mathrm{a}}$

\begin{tabular}{|c|c|c|c|c|c|}
\hline \multirow[t]{2}{*}{ Model } & \multicolumn{2}{|c|}{$\begin{array}{c}\text { Unstandardized } \\
\text { Coefficients }\end{array}$} & \multirow{2}{*}{$\begin{array}{c}\text { Standardized } \\
\text { Coefficients } \\
\text { Beta }\end{array}$} & \multirow[t]{2}{*}{$T$} & \multirow[t]{2}{*}{ Sig. } \\
\hline & $\boldsymbol{B}$ & Std. Error & & & \\
\hline 1 (Constant) & 7,556 & 2,549 & & 2,964 &, 004 \\
\hline Persepsi Nasabah &, 760 & ,076 & 692 & 9,958 &, 000 \\
\hline
\end{tabular}

Berdasarkan Tabel 6, terdapat persamaan regresi linier sederhana sebagai berikut: $\mathrm{Y}=\mathrm{a}+\mathrm{b} . \mathrm{X}=7,556+0,760 \mathrm{X}$. Nilai konstanta sebesar 7,556 menyatakan bahwa jika tidak ada nilai bagi hasil maka persepsi nasabah sebesar 0,760. Koefisien regresi $\mathrm{X}$ sebesar 0,298 menyatakan bahwa setiap penambahan 1 nilai bagi hasil, maka nilai persepsi nasabah bertambah sebesar 0,264.

\section{Uji Determinasi}

Tabel 7 Model Summary

\begin{tabular}{lcccc}
\hline Model & $\boldsymbol{R}$ & $\boldsymbol{R}$ Square & $\begin{array}{c}\text { Adjusted } \\
\boldsymbol{R} \text { Square }\end{array}$ & $\begin{array}{c}\text { Std. Error of the } \\
\text { Estimate }\end{array}$ \\
\hline $1 \quad, 692^{\mathrm{a}}$ & $, 479 \quad, 474$ & 3,96111 \\
a. Predictors: (Constant), Persepsi Nasabah & \\
b. Dependent Variable: Bagi Hasil \\
Sumber: output SPSS
\end{tabular}

Nilai R Square pada tabel 7 sebesar 0,479. Angka R Square disebut juga sebagai koefisien determiansi 0,479 atau sama dengan 47,9\%. Angka tersebut berarti bahwa sebesar 47,9\% variabel bagi hasil mempengaruhi variabel persepsi nasabah. Sementara sisanya, yaitu 69,2\% (100\%-47,9\%) persepsi nasabah dipengaruhi oleh faktor-faktor lain. Besarnya pengaruh faktor lain disebut sebagai eror (e). Untuk menghitung nilai eror dapat digunakan rumus $e=1-r^{2}$. Sebagai catatan, besarnya R Square berkisar antara 0-1. Semakin kecil nilai R Square, maka hubungan variabel semakin lemah. Sebaliknya jika R Square semakin mendekati 1, maka kedua variabel semakin kuat.

\section{Sistem Perhitungan Bagi Hasil Deposito Pada PT. Bank Syariah Mandiri Kantor Cabang Pembantu Bengkalis}

Prinsip bagi hasil merupakan landasan operasional uatam bagi produkproduk pembiayaan mudharabah dan musyarakah dalam perbankan syariah.Untuk menghindarkan masyarakat Islam terlibat amalan riba Bank Syariah Mandiri KCP Bengkalis pada tahun 2010 telah membuka produk-produk tabungan Bank dengan akad mudharabah diantaranya, Tabungan BSM Investa Cendekia, Tabungan Berencana BSM, Deposito BSM, Tabungan BSM dan lain sebagainya. Sedangkan 
produk tabungan Bank dengan akad wadi'ah yaitu, Tabungan Simpatik, Tabungan Giro BSM, dan TabunganKu.

Bank Syariah Mandiri KCP Bengkalis merupakan salah satu lembaga keuangan syariah yang menawarkan simpanan mudharabah berjangka (deposito) yang penarikannya hanya dapat dilakukan pada waktu tertentu berdasarkan perjanjian yang telah ditentukan antara nasabah dengan pihak bank.

Nisbah bagi hasil merupakan persentase keuntungan yang akan diperoleh shahibul mal dan mudharib yang ditentukan berdasarkan kesepakatan antara keduanya. Adapun nisbah yang diperoleh pihak bank dan nasabah terhadap produk deposito yaitu:

Tabel 8 Nisbah Bagi Hasil

\begin{tabular}{ccc}
\hline Jangka Waktu & Nisbah Nasabah & Nisbah Bank \\
\hline 1 Bulan & $46 \%$ & $54 \%$ \\
3 Bulan & $47 \%$ & $53 \%$ \\
6 Bulan & $48 \%$ & $52 \%$ \\
12 Bulan & $49 \%$ & $51 \%$ \\
\hline
\end{tabular}

Sumber: Bank Syariah Mandiri

Pembiayaan dengan pola bagi hasil diterapkan untuk pembiayaan produktif dimana usaha yang dibiayai akan menghasilakan suatu keuntungan atau revenue. Bank diawal akad akan menghitung pendapatan yang diharapkan (expected return) bila bank memberikan pembiayaan kepada nasabah. Selanjutnya expected return tersebut akan disimulasikan dengan proyeksi revenue dari usaha yang dibiayai akan dihasilakan suatu angka proporsi bagi hasil antara bank dan nasabah yang disebut dengan nisbah. Nisbah inilah yang akan menjadi patokan bagi bank dan nasabah dalam berbagi hasil.

\section{Pengaruh Bagi Hasil Deposito Terhadap Persepsi Nasabah Pada PT. Bank Syariah Mandiri Kantor Cabang Pembantu Bengkalis}

Berdasarkan Tabel 5 hasil korelasi antara kedua variabel yang menghasilkan angka 0,692 dengan nilai probabilitas (sig) 0,000. Hal ini menyatakan bahwa korelasi antara bagi hasil dan persepsi nasabah berhubungan secara nyata, karena nilai probabilitas $(0,000<0,05)$.

Berdasarkan Tabel 6 , pengujian hipotesis dalam penelitian ini dapat dijabarkan bahwa taraf signifikasi 5\% dan df (derajat kebebasan) atau n-k $=108$ sehingga $t_{\text {tabel }}$ didapat sebesar 4,320 dan $t_{\text {hitung }}$ sebesar 9,958. Dengan dilakukan uji parsial dapat dikatakan bahwa nilai $t_{\text {hitung }}>t_{\text {tabel }}$ maka hipotesis diterima, sehingga dapat dikatakan bagi hasil mempengaruhi persepsi nasabah.

Identifikasi Determinan $\left(\mathrm{R}^{2}\right)$ berfungsi untuk mengetahui signifikan variabel maka harus dicarai koefisien determinan menunjukkan besarnya kontribusi variabel independent terhadap variabel dependent. Semakin besar nilai koefisien determinasi, maka semakin baik kemampuan variabel independent menerangkan variabel dependent.

Nilai R dalam Tabel 7 menjelaskan bahwa korelasi atau hubungan sebesar 0,692. Kuatnya hubungan suatu variabel berkisar antara $0-1$. semakin mendekati 1, variabel tersebut memiliki hubungan yang kuat diantara keduanya. Sehingga dapat diartikan bahwa bagi hasil mempunyai hubungan yang kuat terhadap persepsi nasabah sebesar 0,692. 
Nilai R Square pada Tabel 7 sebesar 0,479. Angka R Square disebut juga sebagai koefisien determiansi 0,479 atau sama dengan 47,9\%. Angka tersebut berarti bahwa sebesar 47,9\% variabel bagi hasil mempengaruhi variabel persepsi nasabah. Sementara sisanya, yaitu 69,2\% (100\%-47,9\%) persepsi nasabah dipengaruhi oleh faktor-faktor lain. Besarnya pengaruh faktor lain disebut sebagai eror (e). Untuk menghitung nilai eror dapat digunakan rumus $e=1-r^{2}$. Sebagai catatan, besarnya R Square berkisar antara 0-1. Semakin kecil nilai R Square, maka hubungan variabel semakin lemah. Sebaliknya jika R Square semakin mendekati 1, maka kedua variabel semakin kuat.

Nilai Standar Error of Esimate (SEE) pada tabel diatas ialah 3.96111. nilai ini akan digunakan untuk meniali kelayakan preditor (variabel bebas) dalam kaitannya dengan variabel tergantung. Jika nilai SEE < nilai standar deviasi, maka prediktor yang digunakan untuk memprediksi variabel tergantung sudah layak. Pada tabel hasil output diatas, nilai SEE < nilai standar deviasi untuk variabel tergantung bagi hasil $(3,96111<4.97134)$. Ini artinya variabel persepsi sudah layak dijadikan prediktor untuk variabel bagi hasil.

\section{KESIMPULAN}

Prinsip bagi hasil merupakan landasan operasional utama bagi produkproduk pembiayaan mudharabah dan musyarakah dalam perbankan syariah. Sedangkan produk Deposito Bank Syariah Mandiri menggunakan Akad mudharabah. Berdasarkan pada uji parsial yang dilakukan pada penelitiannya, menyajikan deskripsi dari pasangan variabel yang meliputi jumlah data nasabah bagi hasil 110 responden dengan rata-rata 32,6636 dengan standar deviasi 5,46092. Sedangkan jumlah data persepsi nasabah dengan responden 110 juga dengan rata-rata 33,0364 dan standar deviasi 4,97134. Variabel persepsi sudah layak dijadikan prediktor untuk variabel bagi hasil. Kemudian terdapat pengaruh antara bagi hasil terhadap persepsi nasabah pada Bank Syariah Mandiri Kantor Cabang Pembantu Bengkalis, dengan besar pengaruh 47,9\% .

\section{DAFTAR PUSTAKA}

Anshari, Abdul Ghafur. 2007. Perbankan Syariah di Indonesia. Yogyakarta: Gadjah Mada University Press.

Antonio, M. Syafi'i. 2001. Bank Syariah Teori dan Praktek. Jakarta: Gema Insani. Ascarya. 2013. Akad \& Produk Bank Syariah. Jakarta: PT. RajaGrafindo Persada. Arifin, Zainul. 2005. Dasar Dasar Manajemen Bank Syariah. Jakarta: Pustaka Alfabet.

Dewan Syariah Nasional. 2003. Himpunan Fatwa Dewan Syariah Nasional. Jakarta: PT. Intermasa.

Harahap, Sofyan Syafri. 2004. Akuntansi Islam. Jakarta: PT Bumi Aksara.

Hasan, Ali. 2010. Marketing Bank Syariah. Jakarta: Ghalia indonesia.

Hasan, M. Ali. 2003. Berbagai Macam Transaksi dalam Islam. Jakarta: Raja Grafindo Persada. 
Imron. 2016. "Persepektif Hukum Islam Terhadap Biaya Penalty Deposito Mudharabah Pada PT. Bank Syariah Mandiri KCP Bengkalis". Skripsi. Sekolah Tinggi Ilmu Ekonomi (STIE) Syari'ah.

Ismail. 2011. Perbankan Syariah. Jakarta: Kencana Prenadamedia Group.

Israhadi, Evita Isretno. 2011. Pembiayaan Mudharabah Dalam Sistem Perbankan Syariah. Jakarta: Cintya Press.

Karim, Adiwarman A. 2013. Bank Islam: Analisis Fiqih dan Keuangan. Jakarta Raja Grafindo Persada.

Kasmir. 2006. Manajemen Perbankan. Jakarta: PT. Rajagrafindo Persada.

Laksmana, Yusak. 2009. Panduan Praktis Account Officer Bank Syariah, Memahami Praktik Proses Pembiayaan Di Bank Syariah. Jakarta: PT. Elex Media Komputindo.

Lewis, Mervyn K. \& Latifa M Algaoud. 2007. Perbankan Syariah,Prinsip,Praktik dan Prospek. Jakarta: PT. Serambi Ilmu Semesta.

Muhamad. 2014. Manajemen Dana Bank Syariah. Jakarta: PT. Raja Grafindo Persada.

Muhamad. 2016. Sistem Bagi Hasil dan Pricing Bank Syariah. Yogyakarta: UII Press.

Noor, Juliansyah. 2011. Metodologi Penelitian. Jakarta: Kencana Pradamedia Group.

Ridwansyah. 2013. Mengenal Istilah-Istilah Dalam Perbankan Syariah. Bandar Lampung: CV. Anugrah Utama Raharja.

Rivai, Veithzal. 2010. Islamic Banking. Jakarta: PT.Bumi Aksara.

Sjahdeini, Sutan Remy. 2014. Perbankan Syariah, Produk-Produk Dan AspekAspek Hukumnya. Jakarta: Kencana, Prenadamedia Group.

Sofia, Wan. 2013. "Kontribusi Produk Deposito Mudharabah Terhadap Peningkatan Jumlah Nasabah Pada PT. Bank Syariah Mandiri KCP Bengkalis". Skripsi. Sekolah Tinggi Ilmu Ekonomi (STIE) Syari'ah.

Suhendi, Hendi. 2002. Fiqh Muamalah. Jakarta: PT. Raja Grafindo Persada.

Sumitro, Warkum. 2004. Asas-Asas Perbankan Islam Dan Lembaga-Lembaga Terkait. Jakarta: PT. Grafindo Persada.

Syafei, Rachmat. 2001. Fiqh Muamalah. Bandung: Pustaka Setia.

Syamsurizal, Chandra. 2012. Pengertian Nasabah. Diakses dari halaman web: http://pengertiannassabah.blogspot.com/?m=1 tanggal 20 Desember 2017.

Tarmizi. 2014. "Analisis Manajemen Funding BSM Deposito Mudharabah PT. Bank Syariah Mandiri KCP Bengkalis". Skripsi. Sekolah Tinggi Ilmu Ekonomi (STIE) Syari'ah. 